\title{
Masjid Jami Al-Ikhlas Sebagai Pusat Penyebaran Dan Pembinaan Islam (Studi pada Kelurahan Mandomai Kabupaten Kapuas Provinsi Kalimantan Tengah)
}

\author{
Siti Aula Diah ${ }^{\mathrm{a}, 1, *}$, Suryanti ${ }^{\mathrm{b}, 2}$ \\ ${ }^{a, b}$ Institut Agama Islam Negeri Palangka Raya, Palangka Raya 73112, Indonesia \\ Isuryantianthy95@gmail.com
}

Article history:

Received : 2019-10-31

Revised : 2019-12-24

Accepted : 2019-12-25

Keywords:

Functionalization,

Mosque,

Islamic Spreading

Kata kunci:

Fungsionalisasi,

Masjid,

Penyebaran Islam
The functionalization of places of worship in this case of mosques for Muslims has been experiencing a lot of development both in terms of architecture and its function for Muslim communities. One of them is the mosque in the Kapuas district of Central Kalimantan province. This study aims to describe how the process of Islamization and the role of the Jami Al-Ikhlas Mosque as a center for spreading Islam and character building of Islam in Kapuas Regency. The research method uses a descriptive qualitative field research. To collect data, the study uses observation, interviews and documentation. The findings of this study indicate that the process of islamization through marriage, Sufism and martial arts. In addition, the mosque also functions as the Islamic teaching place, the recitation of adult, learning to recite Al-Qur'an for children and habsyi activities.

\begin{abstract}
ABSTRAK
Fungsionalisasi tempat ibadah dalam hal ini masjid bagi umat muslim banyak mengalami perkembangan baik dari aspek arsitektur dan fungsinya bagi masyarakat muslim. Salah satunya di kabupaten Kapuas provinsi Kalimantan Tengah. Penelitian ini bertujuan untuk mendeskripsikan bagaimana proses Islamisasi dan peran Masjid Jami Al-Ikhlas sebagai pusat penyebaran dan pembinaan agama Islam di Kabupaten Kapuas. Adapun metode penelitian ini menggunakan metode lapangan (field research) yang bersifat deskriptif kualitatif. Untuk mengumpulkan data menggunakan observasi, wawancara dan dokumentasi. Temuan penelitian ini menunjukkan bahwa proses islamisasi melalui jalur perkawinan, ilmu tasawuf dan seni bela diri/silat. Selain itu juga masjid berfungsi sebagai Majelis Ta'lim, pengajian bapak-bapak, belajar mengaji anak-anak dan kegiatan habsyi.
\end{abstract}

\section{Pendahuluan}

Kalimantan yang pada masa lampau disebut Borneo merupakan pulau terbesar di Indonesia setelah Irian Jaya memiliki penduduk lokal yang disebut dengan suku Dayak.(11) Suku Dayak di Kalimantan tersebar di berbagai daerah seperti di Serawak, Malaysia, Kalimantan Utara, Kalimantan Timur, Kalimantan Selatan, dan DOI: $10.23971 /$ jsam.v15i2.1621
Kalimantan Barat dengan berbagai keanekaragaman bahasa dan pola hidup yang berbeda antara satu dan yang lainnya.

Penyebaran agama Islam di Nusantara banyak dilakukan oleh para pedagang yang berasal dari bangsa Arab, Persia dan India yang datang dengan tujuan untuk melakukan perdagangan juga sekaligus menyebarkan agama Islam.(5) Wilayah yang pertama kali 
disinggahi oleh para pedagang Arab di wilayah Nusantara adalah pesisir Sumatera. Beranjak dari proses perdagangan di pesisir Sumatera inilah kemudian awal mula munculnya kerajaan-kerajaan yang bercorak Islam. Hal ini tidak terlepas karena adanya proses inkulturasi yang dilakukan oleh para pedagang Arab melalui perdagangan dan pernikahan dengan orang pribumi yang kebanyakan non muslim. Berdasarkan proses ini melahirkan kerajaan-kerajaan bercorak Islam yang semakin berkembang. Diperkirakan pada abad ke-13 M, kerajaan yang pertama kali bercorak Islam di Nusantara adalah Samudra Pasai, pesisir Timur Laut Aceh, dan Kabupaten Lhokseumawe atau Aceh Utara. (12)

Masuknya Islam di Nusantara tidaklah dalam waktu yang bersamaan, begitu juga masuknya Islam di pulau Kalimantan yang awalnya masih menganut kepercayaan leluhur, Hindu dan Budha. Pada akhir abad ke-15, agama Islam masuk ke Kalimantan melalui 2 jalur. Jalur pertama, Islam dibawa melalui Malaka yang dikenal sebagai Kerajaan Islam setelah Perlak dan Pasai. Jatuhnya Malaka ketangan penjajahan Portugis membuat dakwah semakin menyebar di Pulau Kalimantan melalui para mubaligmubalig dan komunitas Islam yang kebanyakan mendiami pesisir Barat Kalimantan. Jalur kedua, dakwah Islam dibawa melalui para mubalig yang dikirim langsung melalui Jawa yang mencapai puncaknya ketika berdirinya Kerajaan Islam Banjar.(9)

Adapun menurut peneliti sendiri masuknya Islam di Pulau Kalimantan memang tidak lepas dari pengaruh para mubalig dan pedagang yang selain melakukan perdagangan juga aktif dalam mensyiarkan agama Islam. Hal tersebut dikarenakan Pulau Kalimantan sendiri memiliki potensi perairan yang tinggi yang mana hal ini sesuai dengan jalur penyebaran Islam yaitu jalur laut ataupun sungai. Masuknya Islam di Kabupaten Kapuas kalimantan Tengah dapat diperkirakan pada tahun $1810 \mathrm{M}$ hingga sampai kelurahan Mandomai pada Tahun 1903 dibuktikan dengan adanya bangunan Masjid Jami sebagai Masjid Pertama di Kelurahan Mandomai.(1)

Kelurahan Mandomai dikenal dengan sebutan kota tua yang mana dibuktikan dengan adanya penemuan sebuah sandung yang bernama "Tahuntun Pantar" yang bertuliskan angka $1735 \mathrm{M}$. Sebelum bernama Mandomai dulu daerah ini dikenal dengan sebutan Tacang Tangguhan. Banyak pendapat yang bermunculan mengenai arti dari kata Mandomai tersebut, ada yang mengatakan diberikan oleh orang - orang Banjar sebagai warga pendatang dimana Mandomai di ambil dari kata bahasa Dayak Ngaju " Mandui Mai "yang artinya " Ibu mandi " akibat orang orang Banjar sering mendengar percakapan tersebut dari lisan orang Dayak, atas dasar itulah mereka memberi nama kampung Mandomai. Ada juga pendapat lain yang menyatakan Mandomai diambil dari kata "Man = aman" dan "Domai = Damai" apabila digabung Mandomai berarti Desa yang Damai.(19) Islam masuk ke daerah Mandomai melewati jalur perniagaan, para pedagang yang berniaga tersebut berasal dari daerah Kuin, Banjarmasin (dulunya bernama Bandarmasih) yang terlebih dahulu memeluk Agama Islam. Selain melakukan perdagangan mereka juga aktif mensyiarkan agama Islam.

Salah satu bukti perkembangan Islam di Kelurahan Mandomai Kabupaten Kapuas Kalimantan Tengah ditandai dengan adanya bangunan Masjid tua yang dibangun pada tahun 1903 M, tepatnya yaitu pada tanggal 04 Agustus 1903 M yang dinamai dengan Masjid Jami Al-Ikhlas. Masjid tersebut dibangun oleh 4 tokoh masyarakat yaitu Abdurrahman bin $\mathrm{H}$. Muhammad Arsyad berasal dari Kuin, Abdullah bin H. Muhammad (penghulu Mandomai), Sabri bin H. Muchtar, Sahaboe bin H. Muhammad Aspar. Nama-nama para pembangunan Masjid ini terpahat di 4 tiang Masjid Jami Al-Ikhlas yang disebut sebagai "4 tiang guru".(1) Hingga saat ini Masjid tersebut masih berdiri dengan kokoh dengan mengalami beberapa kali perenovasian namun tidak menghilangkan bentuk asli dari Masjid ini. Masjid Jami Al-Ikhlas ini merupakan salah satu Masjid tertua yang ada di Kalimantan Tengah yang berumur kurang lebih 116 tahun. Masjid Jami Al-Ihklas berfungsi sebagai sarana beribadah, tempat untuk melakukan kegiatan pendidikan keagamaan, juga merupakan pusat penyebaran Islam di Kelurahan Mandomai Kabupaten Kuala Kapuas. Berdasarkan uraian latar belakang di atas, dapat dirumuskan pokok masalah sebagai berikut: 
bagaimana proses masuknya Islam di Kelurahan Mandomai Kabupaten Kapuas Kalimantan Tengah?, (1) bagaimana peran Masjid Jami Al-Ikhlas sebagai pusat penyebaran dan pembinaan Islam di Kelurahan Mandomai Kabupaten Kapuas Kalimantan Tengah? penelitian ini bertujuan untuk mendeskripsikan bagaimana sejarah dan proses masuknya agama Islam di Kelurahan Mandomai Kabupaten Kapuas, dan menjelaskan tentang bagaimana peran dari Masjid Jami Al-Ikhlas sebagai pusat penyebaran dan pembinaan agama Islam di Kelurahan Mandomai Kabupaten Kapuas.

\section{Review Tinjauan Pustaka}

Masuknya Islam ke pulau Kalimantan dibawah oleh para pedagang dan mubalig Islam yang berasal dari Keling, Gujarat, Melayu, Bugis, dan Biaju. Perkembangan Islam di Kalimantan semakin meluas ketika berdirinya Kesultanan Banjar dan Kesultanan Kutai. Menurut Hikayat Banjar masuknya Islam di Kalimantan itu sendiri diawali dengan pertikaian antara Pangeran Samudera dan Pangeran Tumenggung atas perebutan kekuasaan yang mana Pangeran Samudera merupakan pewaris sah Kerajaan Daha.(8) Namun direbut oleh pamannya sendiri yaitu Pangeran Tumenggung. Merasa kekuatannya tidak cukup untuk merebut kekuasaan lantas ia berkelana menelusuri Tamban, Muhur, Baladean, Belitung hingga sampai ke Pulau Jawa dan meminta bantuan Kesultanan Demak.(7) Kesultanan Demak bersedia membantu dengan syarat Pangeran Samudera mau memeluk agama Islam dan jika menang Pangeran Samudera bertanggung jawab dalam menyebarkan agama Islam ke wilayah Kalimantan. Syarat tersebut lantas disetujui Pangeran Samudera dan Demak mengirimkan 1000 balatentara lengkap dengan persenjataanya serta seorang penghulu bernama Khatib Dayan untuk mengislamkan orang-orang Banjar.(19) Dalam peperangan itu, pangeran Samudera memperoleh kemenangan dan sesuai dengan janjinya ia beserta keluarga keraton dan penduduk Banjar menyatakan diri masuk Islam. Namun menurut sumber lain, melihat kekuatan Pangeran Samudera yang begitu besar, Pangeran Tumenggung mengurungkan niatnya untuk berperang dan memilih jalan damai dan menyerahkan tampuk kerajaan kepada Pangeran Samudera.(6) Setelah masuk Islam Pangeran Samudera sendiri berubah nama menjadi Sultan Suryanullah atau Surianyah, yang dinobatkan sebagai Raja pertama dalam kerajaan Islam di Banjar pada tahun 1526 M. Disamping memperluas kekuasaan Kesultanan Banjar juga berusaha mengembangkan ajaran Islam hingga sampai ke wilayah Kapuas. Masuknya Islam di Kapuas belum diketahui secara pasti namun ada sumber yang mengatakan bahwa Islam masuk di Kapuas sekitar tahun 1810 M yang dibawa oleh para pedagang yang berasal dari Banjarmasin.

Islam masuk ke pulau Kalimantan melalui tiga jalur. Pertama, melalui Malaka yang dikenal sebagai Kesultanan Islam setelah Perlak dan Pasai.(12) Kedua, Islam datang dan disebarkan oleh para mubaligh dari tanah Jawa. Ekspedisi dakwah ke Kalimantan ini mencapai puncaknya saat kerajaan Demak berdiri. Ketiga para da'i datang dari Sulawesi (Makasar) terutama da'i yang terkenal saat itu adalah Datuk Ri Bandang dan Tuan Tunggang Parangan.(13)

Islam masuk di kelurahan Mandomai Kabupaten Kapuas melalui beberapa saluran yaitu Pengajaran Tasawuf (kebatinan) sifat 20, pendidikan, kesenian, perdagangan, dan perkawinan. Salah satu bukti perkembangan Islam di Kelurahan Mandomai Kabupaten Kapuas ialah berdirinya sebuah Masjid pertama yaitu Masjid Jami Al-Ikhlas di Kelurahan Mandomai pada tahun 1903 M. Masjid tersebut selain berperan dalam penyebaran Islam di wilayah Mandomai juga dijadikan sebagai wadah untuk melakukan kegiatan-kegiatan keagamaan lainnya.(1)

\section{Metodologi Penelitian}

Penyusunan penelitian ini menggunakan jenis penelitian lapangan (field research), yaitu penyusun mengadakan penyelidikan berdasarkan pada objek penelitian atau lapangan, dalam hal ini yang menjadi objek penelitian adalah peran dari Masjid Jami AlIkhlas dalam proses penyebaran dan pembinaan agama Islam di Kelurahan Mandomai Kabupaten Kapuas. Oleh karena itu jenis data yang diperlukan dalam penelitian ini ialah terdiri dari data primer atau pokok dan data sekunder atau pelengkap.

Data primer atau pokok yang meliputi data-data yang berhubungan dengan 
masuknya Islam di Kelurahan Mandomai Kabupaten Kuala Kapuas dan sejarah dibangunnya Masjid Jami Al-Ikhlas sebagai bentuk penyebaran Islam di Kelurahan Mandomai Kabupaten Kuala Kapuas Kalimantan Tengah. Sedangkan data sekunder adalah data pendukung atau pelengkap yang ada hubungannya dengan permasalahan yang akan diteliti yang mana sesuai dengan metode penulisan sejarah: Pertama Heuristik pengumpulan sumber-sumber sejarah.(16) Pengumpulan sumber-sumber sejarah ini dilakukan melalui wawancara langsung kepada responden yang berjumlah sekitar 15 orang yaitu masyarakat yang tinggal di lokasi penelitian seperti pengurus masjid Jami AlIkhlas yang mempunyai arsip-arsip berupa kumpulan-kumpulan tulisan mengenai sejarah terbentuknya Masjid Jami Al-Ikhas, tulisan tersebut menggunakan bahasa Indonesia. Kaum masjid Jami Al-Ikhlas, imam Masjid Jami Al-Ikhlas, keturunan-keturunan baik keturunan dari pendiri Masjid Jami Al-Ikhlas ataupun para penyebar agama Islam di Mandomai yang mana berdasarkan informasi yang ada keturunan yang masih hidup ialah keturunan ke-7 dari sang pendiri. Setelah itu data dilengkapi dengan menggunakan teknik dokumentasi, yang mana dimaksud dokumentasi disini ialah mendokumentasikan artefak/sisa-sisa peninggalan dari pendirian Masjid Jami Al-Ikhlas.

Kedua, kritik sumber yang mana setelah data yang didapatkan dari hasil wawancara tersebut dikumpulkan setelahnya akan dilakukan kritik sumber. Kritik sumber ini dilakukan secara internal yang mengacu pada kredibilitas sumber artinya apakah isi dokumen/wawancara yang dilakukan dengan para sumber ini terpecaya, tidak dimanipulasi, mengandung bias, dan dikecohkan.(15) Sedangkan, kritik eksternal yang menekankan aspek luar yang mana berusaha untuk mendapatkan otentisitas sumber dengan melakukan penelitian fisik terhadap hasil wawancara dengan para tokoh di Mandomai.(16) Ketiga, interpretasi setelah data tersebut di kritik kebenaran dan kevalidan datanya maka barulah dilakukan interpretasi yaitu menafsirkan atau menggabungkan makna-makna yang telah di dapat dari hasil wawancara dengan para tokoh di Mandomai dari satu sumber ke sumber lainnya apakah data yang didapat tersebut memiliki kesinambungan atau tidak.(14) Keempat, setelah semua tahapan telah dilakukan maka masuk ke tahap terakhir yaitu historiografi/penulisan sejarah yang nantinya menyampaikan hasil penelitian mengenai Masjid Jami Al-Ikhlas Sebagai Pusat penyebaran dan pembinaan Islam secara tertulis dan dapat dipertanggung jawabkan secara ilmiah.

\section{Hasil dan Diskusi}

a. Sejarah Kelurahan Mandomai

Kelurahan Mandomai, sebelum dinamakan Kelurahan Mandomai dulunya bernama Lewu Tahutun Pantar, Rundung Riak Kaweh Dare nama ini didapat dari hasil musyawarah antar tetua tokoh adat setempat dengan pemimpin Kelurahan Mandomai. Namun, dikarenakan terjadi suatu musibah yang menyerang kampung tersebut lantas nama Lewu Tahutun Pantar, Rundung Riak Kaweh Dare diganti sebutannya dengan nama Mandomai.(8)

Banyak pendapat yang bermunculan mengenai arti dari kata Mandomai tersebut, salah satunya yaitu menurut seorang penduduk Mandomai beliau berkata jika nama Mandomai diberikan oleh orang-orang Banjar sebagai warga pendatang dimana Mandomai di ambil dari kata bahasa Dayak Ngaju yaitu " Mandui Mai "yang artinya " Ibu mandi " akibat orang - orang Banjar sering mendengar percakapan tersebut dari lisan orang Dayak, maka atas dasar itulah mereka memberi nama kampung tersebut sebagai Mandomai.(13) Ada juga pendapat lain yang menyatakan Mandomai diambil dari kata "Man = aman" dan "Domai = Damai" apabila digabung Mandomai berarti Desa yang Damai.(19)

Berdasarkan dengan data yang ada di Masjid Jami Al-Ikhlas. Sekitar abad ke 15 Mandomai pada umumnya masih tergolong tempat yang masih murni yaitu masih hutan belantara dan belum tersentuh oleh para pendatang, sedangkan suku asli yang mendiaminya dinamakan suku Dayak. Sebelum kedatangan para pendatang dari luar, Mandomai dahulu juga dikenal dengan nama Desa Tacang 
Tangguhan, sebuah Desa kecil yang pada kala itu hanya terdapat beberapa kepala keluarga dan tinggal dirumah adat yaitu rumah betang. Masyarakatnyapun waktu itu masih tergolong primitif mereka menggunakan baju dari anyaman rotan, kulit kayu maupun juga kulit hewan. Kepercayaan yang dianut pun masih kepercayaan nenek moyang yaitu Keharingan yang artinya "Kehidupan".

b. Proses Masuknya Islam di Kelurahan Mandomai Kabupaten Kapuas

Masuknya Islam di Kabupaten Kapuas tidak dilakukan secara bersamaan, tingkat penerimaan Islam pada suatu bagian atau bagian lainnya tidak hanya bergantung pada waktu pengenalannya tetapi juga ditentukan pada kebudayaan lokal setempat yang dihadapi Islam nantinya.(4)

Agama Islam diketahui masuk ke Kapuas melalui jalur perdagangan dari wilayah Kalimantan Selatan (Banjarmasin). Para pedagang berlayar dan singgah untuk berdagang di pusatpusat perdagangan di daerah pesisir. Mereka tinggal di tempat-tempat tersebut dalam waktu yang lama untuk menunggu angin musim. Pada saat menunggu inilah, terjadi pembauran antar pedagang dari berbagai daerah dengan penduduk setempat, maka ketika pembauran ini berlangsung terjadilah kegiatan saling memperkenalkan adat-istiadat, budaya bahkan agama. Bukan hanya melakukan perkenalan, namun juga terjadi asimilasi budaya melalui perkawinan tersebut.(9)

Masuknya agama Islam di Kelurahan Mandomai hingga kepedalaman diketahui melalui jalur perdagangan yang berasal dari daerah Nagara, Kalimantan Selatan. Namun ada pendapat lain yang mengatakan ada juga para pedagang yang berasal dari daerah Kuin, Banjarmasin. Para pedagang tersebut melanglang buana dengan menggunakan jukung (perahu) untuk membeli bahan mentah seperti rotan dan karet-karet yang nantinya akan dijual di Banjarmasin. Salah satu tokoh penyebar agama Islam di Kelurahan Mandomai ialah H. Muhammad bin Abdullah. Beliau merantau dari daerah Martapura dengan menggunakan perahu sesampainya di Mandomai ia memutuskan untuk menetap disana dan juga menikah dengan wanita penduduk asli Mandomai. Saat melakukan syiar agama yang dilakukan oleh $\mathrm{H}$. Muhammad ini beliau murni melakukan dakwah tanpa ada pemaksaan. Hingga pada saat itu salah satu tokoh besar Mandomai yaitu Ngabe Ratu bersama Damang Tamus memutuskan untuk masuk Islam.(13) Saat melakukan syiar keagamaan $H$. Muhammad tidaklah seorang diri, ia dibantu oleh 3 orang lagi yaitu: Abdurrahman bin H. Muhammad Arsyad, Syahabu bin H. Muhammad Aspar (Mandomai), dan, Sabri bin H. Muckhtar. Nama keempat pendiri ini terpahat ditiang ulin penyangga dan dinamakan tiang saka guru Masjid Jami ada juga yang mengatakan tiang ini adalah "tiang 4 guru".

Perkembangan Islam di Mandomai secara keseluruhan sekarang ini sangat signifikan. Berdasarkan dari data desa yang ada menunjukan bahwa Islam merupakan agama pendatang yang sangat diminati penduduk Mandomai dan Islam di Mandomai menjadi agama mayoritas. Seperti yang diungkapkan oleh salah seorang penduduk Mandomai, bahwa Islam di Mandomai mencapai $80 \%$ dari total keseluruhan yang ada.(2) Sebagai bukti Islam telah menjadi mayoritas di masyarakat Mandomai ialah banyaknya bangunan Masjid dibandingkan dengan bangunan keagamaan lainnya. Kelurahan Mandomai memiliki 5 bangunan Masjid, 8 bangunan langgar (Musholla) salah satunya Masjid Jami Al-Ikhlas pada tahun 1903 sebagai Masjid pertama yang dibangun di Kelurahan Mandomai

c. Masjid Jami Al-Ikhlas sebagai pusat penyebaran dan pembinaan Islam di Kelurahan Mandomai Kabupaten Kapuas Kalimantan Tengah

1. Sejarah Masjid Jami Al-Ikhlas Kelurahan Mandomai

Berdasarkan sumber informasi yang diperoleh bahwa Masjid yang pertama kali dibangun di Kelurahan Mandomai ialah Masjid Jami AlIkhlas yang tepatnya terletak di Jalan Ria Gilang Rt.08, Kelurahan Mandomai, Kecamatan Kapuas Barat, 
Kabupaten Kuala Kapuas. Masjid ini didirikan pada tanggal 4 Agustus 1903 M, didirikan oleh 4 orang tokoh masyarakat yakni: Syabri bin $\mathrm{H}$. Mukhtar, Syahabu bin H. Muhammad Aspar, Abdurrahman Bin $\mathrm{H}$. Muhammad Arsyad (Kuin) dan Abdullah bin H. Muhammad (penghulu Mandomai).(19) Namanama para pemprakarsai ini terpahat di 4 tiang Masjid Jami Al-Ikhlas dan disebut sebagai "4 tiang guru". Masjid ini memiliki panjang 13,5 M, dan lebar sepanjang 13,5 M, dilihat dari segi arsitekturnya mengadopsi dari Masjid-Masjid yang ada di Kalimantan Selatan. Namun, ada satu pendapat yang mengatakan jika bentuk Masjid ini mengadopsi bentuk Masjid di Kerajaan Demak.(13)

Menurut asumsi peneliti sendiri Masjid Jami Al-Ikhlas Mandomai sejatinya ialah mengambil corak arsitektur perpaduan antara Masjid yang ada di Kalimantan Selatan dan juga dari Masjid Demak. Hal didasarkan pada mulanya Masjid di Kalimantan Selatan juga pada awalnya mendapat pengaruh dari masjid-masjid yang ada di Pantai Utara Jawa, karena penyebaran Islam dan pendiri Masjid pertama di Kalimantan Selatan dilakukan oleh ulama yang berasal dari Kerajaan Demak. Jadi tidak menutup kemungkinan apabila Masjid yang dibangun di Kalimantan Selatan tersebut memiliki perpaduan antara Masjid Demak.(3) beberapa narasumber yang ada Masjid ini ditopang oleh 8 tiang yang terbuat dari kayu ulin dan mempunyai panjang sekitar 10 meter. Dari 8 tiang yang ada, terdapat 4 tiang yang terpahat nama pendiri dan tahun berdirinya. Ukiran yang ada tersebut menggunakan jenis ukiran kaligrafi Arab Melayu. Masjid ini dulunya menggunakan atap yang terbuat dari atap sirap, lantai yang menggunakan kayu ulin dan dindingnya yang menggunakan kayu meranti.(7) Namun dikarenakan Masjid ini telah berdiri cukup lama yaitu lebih dari 1 abad lamanya maka banyak bagianbagian Masjid yang telah lapuk dimakan usia dan juga tidak terawat sehingga diharuskan untuk merombak sebagian besar bentuk Masjid. Jika dihitung dari lamanya Masjid ini berdiri kira-kira Masjid ini sudah mengalami kurang lebih 2 kali renovasi.

Masjid Jami Al-Ikhlas selain sebagai tempat ibadah juga digunakan sebagai tempat pendidikan anak-anak seperti mengaji, pembelajaran Habsyi juga yasinan ibu-ibu setempat. Masjid ini dulunya merupakan Masjid yang digunakan secara bersama-sama oleh kaum Muhammadiyah dan Nahdatul Ulama (NU) di Mandomai, namun seiring dengan berkembangnya Islam di Mandomai hingga menjadi mayoritas seperti sekarang ini maka dibangun juga Masjid-Masjid lainya.

2. Masjid Jami Al-Ikhlas Dalam Bidang Sosial Kemasyarakatan

Masjid Jami Al-Ikhlas selain digunakan sebagai tempat ibadah juga difungsikan sebagai tempat sosial kemasyarakatan. Dalam bidang sosial kemasyarakatan peran masjid sangatlah penting. Masjid Jami AlIkhlas di Kelurahan Mandomai dibangun ditengah-tengah pemukiman warga. Hal ini dimaksudkan untuk memudahkan masyarakat Kelurahan Mandomai melakukan ibadah sholat berjama'ah.Kegiatan dalam bidang sosial dilakukan oleh masyarakat Kelurahan Mamndomai ialah Maulid Habsyi yang rutin dilaksanakan remaja-remaja Masjid Jami AlIkhlas.(6) Kegiatan maulid habsyi di Masjid Jami Al-Ikhlas dilakukan pada malam senin juga malam jum'at setelah shalat isya hingga jam 21:00 WIB. Kegiatan maulid habsyi dilaksanakan oleh remaja-remaja Masjid yang tinggal di sekitaran Mandomai, nama grup habsyi tersebut ialah Miftahus Sholihin. Kegiatan Maulid habsyi di Masjid Jami Al-Ikhlas diikuti oleh anak-anak dan remaja-remaja yang berjumlah 
15-20 orang yang masih aktif bersekolah.

Kegiatan Maulid ini mereka diajarkan cara bagaimana menapak tambang menggunakan bermacammacam pukulan dalam kegiatan habsyi seperti: pukulan gulungan, tingkahan, rasukan, dan bas. Sedangkan rangkaian kegiatan habsyi di Masjid Jami Al-Ikhlas diawali dengan pembacaan Al-Qur'an, dilanjutkan membaca surah yasin, tabarak, surah Al-Wakiah dan terakhir baru dilanjutkan dengan kegiatan habsyi, terkadang juga di dalam kegiatan maulid habsyi ini dilakukan pembacaan Ratib Umar Atthos. Ratib Umar Atthos ini terdapat didalam kitab karangan dari Guru Sekumpul yang berjudul AlImdan, didalam kitab ini selain terdapat bacaan shalawat, dzikir, doadoa juga terdapat bacaan tawassul kepada para wali Allah. Sedangkan untuk syair yang biasa digunakan dalam kegiatan maulid habsyi di Masjid Jami Al-Ikhlas ialah syair dari Guru Sekumpul. Hal ini dikarenakan para remaja Masjid lebih dominan tertarik dengan syair-syair yang dibacakan Guru Sekumpul dibandingkan dengan syair lainnya.(18)

Pada bulan Ramadhan para jamaah Masjid Jami Al-Ikhlas di Kelurahan Mandomai akan melakukan I'tikaf (yaitu sunnah Nabi Muhammad SAW untuk berdiam diri di Masjid guna memperbanyak pahala). Selain itu juga di Masjid Jami Al-Ikhlas menyediakan menyediakan makanan untuk sahur dan berbuka, terkadang sambil menunggu waktu berbuka puasa tidak jarang diselingi dengan ceramah-ceramah bermanfaat seputar keislaman. Sedangkan, pada akhir menjelang lebaran Masjid Jami Al-Ikhlas di Mandomai akan membentuk panitia amil zakat yang berfungsi untuk mengelola zakat fitrah yang telah diberikan oleh masyarakat mampu untuk disalurkan kepada masyarakat yang kurang mampu. Zakat ini dapat berupa uang ataupun sembako.(6)

Masjid Jami Al-Ikhlas juga sering digunakan sebagai tempat dilangsungkannya acara akad nikah masyarakat Kelurahan Mandomai, sebagai tempat untuk mengislamkan masyarakat mandomai yang ingin masuk agama Islam lalu setelahnya akan dilakukan juga pembinaan bagi para mualaf yang baru memeluk agama Islam, pembinaan ini diajarkan oleh Gusti M. Maulana Khardimand beliau juga merupakan staf di KUA (Kantor Urusan Agama) Mandomai. Mereka diajarkan dakwah keislaman, menjadi khatib, muadzin, dan imam.(10) Kegiatan ini dilakukan setiap malam sabtu di Masjid Jami Al-Ikhlas Mandomai.(15) Kegiatan ini dimaksudkan untuk lebih menguatkan keimanan bagi mualaf dan lebih mendalami keislaman mereka.

3. Peran Masjid Jami Al-Ikhlas Dalam Bidang Keagamaan Dan Pendidikan

Masjid Jami Al-Ikhlas Kelurahan Mandomai sebagai tempat pendidikan keagamaan seperti: TPA (Taman Pembelajaran Al-Qur'an), dan juga Majelis Ta'lim baik ibu-ibu ataupun bapak-bapak.Masjid Jami Al-Ikhlas memiliki TPA tersendiri, di TPA ini mereka belajar mengaji dari dasar yaitu mengenal huruf hijaiyah sampai dengan membaca Al-Qur'an sekaligus mengenal dan mempelajari hukum bacaan (tadjwid) dalam AlQur'an. Kegiatan ini biasanya dilakukan di dalam Masjid Jami AlIkhlas atau juga dirumah pengajarnya. Kegiatan ini biasanya dilaksanakan setelah dzuhur, hal ini dikarenakan menunggu anak-anak pulang sekolah. Pembelajaran disini menggunakan sistem perorangan yaitu apabila satu murid telah selesai akan berganti dengan murid selanjutnya. Murid yang belajar mengaji mayoritas merupakan anak-anak yang masih bersekolah di sekolah dasar. Belajar mengaji ini tidak diwajibkan untuk membayar dan yang menjadi tenaga pengajar juga merupakan imam yang 
sehari-harinya menjadi Imam di Masjid tersebut.(6) Selain, TPA di Masjid Jami Al-Ikhlas juga dilaksanakan kegiatan TKA (Taman Kanak-Kanak Al-Qur'an) yang belajar disini ialah anak-anak 4-8 tahun, dan TQA (Taman Qira'at AlQur'an) dimulai dari 13-dewasa.

Masjid Jami Al-Ikhlas selain dijadikan sebagai tempat belajar bagi anak-anak TPA Masjid ini juga difungsikan sebagai tempat yasinan ibu-ibu pengajian dengan rangkaian acara pertama membaca Al-Qur'an, dilanjutkan dengan pembacaan surah yasin, shalawat atau puji-pujian kepada baginda Rasulullah SAW dan diakhiri dengan ceramah/tausiyah keagamaan. Yasinan ibu-ibu ini biasanya dilaksanaan rutinan setiap hari selasa siang setelah dzuhur.(13) Masjid Jami Al-Ikhlas juga dijadikan sebagai tempat Majelis Ta'lim ibuibu yang diajarkan oleh 5 (lima) orang da'i yang berasal dari Yogyakarta.(2) Akan tetapi Majelis Ta'lim di Masjid Jami Al-Ikhlas sekarang terbagi menjadi dua yaitu Majelis Ta'lim ibuibu Khairun Nisa sedangkan Majelis Ta'lim bapak-bapak bernama AlIkhlas.

Majelis Ta'lim ibu-ibu dilaksanakan setiap hari kamis pukul 13:00-15:00 WIB. Majelis Ta'lim ibu-ibu ini diajarkan oleh Pak Yazid Fahmi atau lebih sering dikenal dengan Guru Fahmi. Materi dakwah yang disampaikan beliau kepada anggota pengajian Majelis Ta'lim antara lain adalah: Tauhid (meliputi Rukun Iman, sifat-sifat Allah dan lain-lain.), Fiqh (meliputi shalat, thaharah, wudhu dan lain-lain), Akhlak (meliputi; Akhlak/budi pekerti dengan Allah dan dengan sesama manusia) dan Tasawuf (yang berhubungan dengan pengenalan terhadap Allah dan lain-lain) karena materi tersebut banyak menjawab persoalan-persoalan di masyarakat. Sedangkan metode dakwah yang digunakan pada Majelis Ta'lim Masjid Jami Al-Iklas Mandomai ialah metode ceramah, metode tanya jawab, metode dengan cara hikmah, dan metode pelajaran yang baik. Tujuan diadakan Majelis Ta'lim ini ialah agar menambah wawasan masyarakat Mandomai tentang ilmu agama. Majelis Ta'lim ini dilaksanakan setiap minggu setelah dzuhur sampai dengan ashar.(6)

Sedangkan, Majelis Ta'lim bapak-bapak dilaksanakan setiap malam sabtu setelah Isya sampai selesai oleh Gusti M. Maulana Khardiman. Rangkaian acara kegiatan Majelis Ta'lim bapak-bapak dimulai dengan pembacaan surah yasin, Shalawat Nariyah, Mazhab Syarif, doa dan terakhir yaitu ceramah/tausiyah keagamaan.(10)

4. Peran Masjid Jami Al-Ikhlas Sebagai Pusat Penyebaran dan Pembinaan Agama Islam

Masjid merupakan sebuah tempat ibadah yang mempunyai banyak fungsi bagi kemaslahatan umat, sehingga pengelolaan dan manajemen yang baik dan benar sangat dibutuhkan untuk menjadikan Masjid sebagai pusat peradaban Islam. Maka dari itu, pengurus takmir Masjid hendaknya bersikap proaktif dalam menjadikan masjid sebagai tempat ibadah, tempat membina umat, mengayomi masyarakat dan menjadi media dakwah dalam upaya peningkatkan dakwah Islam. Apabila masjid dikelola dengan baik dan benar maka masjid tersebut akan memiliki daya tariknya tersendiri bagi umat muslim untuk berkunjung walaupun hanya untuk menunaikan ibadah shalat fardu, dari kunjungan tersebut maka akan membawa dampak positif bagi perkembangan fungsi masjid dari sekedar tempat ibadah menjadi tempat pengembangan dakwah, berkomunikasi, membina ukhuwah Islamiyah dan aktivitas lainnya yang berhubungan dalam pengembangan Islam. Maka pengurus Masjid dituntun untuk aktif membuat kegiatan-kegiatan yang menarik minat dari pengunjung sehingga 
masjid berfungsi sebagaimana fungsi awalnya.

Pada masa kejayaan Islam masjid tidak hanya sebagai tempat ibadah saja, akan tetapi memiliki fungsi yang lebih luas dari pada itu sebagai pusat intelektualitas. Sejak pertama kali didirikan oleh Rasulullah SAW, masjid telah menjadi pusat kegiatan keislaman, tempat menunaikan shalat, berdakwah, mendiskusikan politik, dan sekolah. Masjid merupakan jantung kehidupan bagi umat Islam yang berfungsi untuk menyebarluaskan dakwah Islam juga budaya Islam yang berguna untuk menjawab kebutuhan masyarakat muslim, karena itulah Masjid berperan sebagai pusat penyebaran Islam. Masjid merupakan intuisi pertama yang menjadi titik tolak penyebaran Islam juga merupakan batu loncatan pertama untuk melakukan dakwah Islam yang membawa kekhususan asasi kepada masyarakat muslim.(17)

Masjid sebagai pusat peradaban adalah masjid yang fungsinya bukan hanya sebagai tempat untuk melaksanakan ibadah shalat semata akan tetapi memiliki fungsi yang lebih luas dari pada itu yaitu sebagai tempat untuk melakukan penyebaran agama Islam dan tempat untuk melaksanakan kegiatan-kegiatan keislaman baik dalam bidang agama, pendidikan, sosial, ekonomi, dan seni budaya.Hal ini juga terjadi pada masjid Jami Al-Ikhlas yang apabila dilihat dari segi historisnya Masjid ini merupakan Masjid pertama yang dibangun pada awal penyebaran Islam di Mandomai bahkan salah satu Masjid tertua di Kalimantan Tengah, maka secara tidak langsung Masjid ini pulalah yang menjadi pusat dakwah Islam dan pusat penyebaraan Islam di Mandomai pada saat awal-awal keislaman.Masjid Jami Al-Ikhlas juga difungsikan sebagai tempat pendidikan keagamaan seperti sebagai tempat pembinaan muslim dan kepemimpinan umat Islam.

\section{Kesimpulan}

Berdasarkan dari hasil penelitian tentang Masjid Jami Al-Ikhlas Sebagai Pusat Penyebaran dan Pembinaan Islam Di Kelurahan Mandomai Kabupaten Kuala Kapuas Kalimantan Tengah dalam hal ini dapat disimpulkan sebagai berikut:

1. Masuknya Islam ke daerah Mandomai dilakukan dengan jalan damai. Islamisasi di Kelurahan Mandomai dilakukan melalui beberapa jalur diantaranya ialah: perdagangan, perkawinan, tasawuf, dan kesenian (seni bela diri/silat). Salah satu tokoh penyebar Islam di Mandomai ialah H. Muhammad bin Abdullah beliau merupakan perantau yang berasal dari Martapura yang menikah dengan gadis pribumi lantas menetap di Mandomai untuk melakukan dakwah Islam. Perkembangan Islam di Kelurahan Mandomai sangat signifikan baik secara kualitas maupun kuantitasnya, hal ini terbukti dari Islam merupakan agama mayoritas yang ada di Mandomai. Masjid Jami Al-Ikhlas didirikan pada tanggal 4 Agustus 1903 M, didirikan oleh 4 orang guru yang bernama:

a. Syabri bin H. Mukhtar

b. Syahabu bin H. Muhammad Aspar

c. Abdurrahman bin H. Muhammad Arsyad

d. Abdullah bin H. Muhammad

Nama-nama dari pendiri ini terpahat di 4 tiang guru Masjid Jami Al-Ikhlas menggunakan kaligrafi Arab Melayu. Secara wujudnya Masjid Jami Al-Ikhlas tidaklah berubah dari bentuk aslinya namun bahan-bahan material pembangunan Masjid Jami Al-Ikhlas sebagian banyak telah berubah, seperti atap, lantai, dan dindingnya. Atap Masjid Jami Al-Ikhlas dulu menggunakan sirap sekarang berganti menggunakan seng sedangkan lantai dan dindingnya yang dulunya menggunakan kayu ulin berubah menggunakan keramik dan beton.

2. Masjid Jami Al-Ikhlas sekarang telah banyak mengalami perkembangan, Masjid tersebut memiliki berbagai fungsi selain sebagai tempat ibadah Masjid Jami AlIkhlas juga dijadikan sebagai tempat penyebaran dan juga pengembangan Islam seperti: 
a. Kegiatan pengajian Taman Pendidikan Al Qur'an (TPA).

b. Tempat kegiatan Remaja Masjid bagi remaja yang ingin menyalurkan bakatnya seperti kegiatan Maulid habsyi yang sekarang ini eksis di Masjid Jami Al-Ikhlas dengan nama grup Miftahus Sholihin.

c. Majelis Ta'lim ibu-ibu yang diajarkan oleh Guru Fahmi mengenai pendidikan keislaman seperti Tauhid, Fiqh, Akhlak, dan Tasawuf .

d. Majelis Ta'lim bapak-bapak yang diajarkan oleh Gusti Muhammad Maulana K dimulai dengan acara yasinan, shalawat nariyah, do'a, ceramah/tausiyah keagamaan.

e. Tempat mengislamkan dan pembinaan muslim yang baru masuk Islam (mualaf).

f. Tempat dilangsungkannya acara akad nikah.

\section{Daftar Pustaka}

1. Anwar K. Kedatangan Islam Di Bumi

Tambun Bungai Cet 1. Banjarmasin:

Comdes Kalimantan, 2005.

2. Arifin. Pelaksanaan Dakwah Pada Majelis Ta'lim Masjid Jami Al-Ikhlas Mandomai Kecamatan Kapuas Barat Kabupaten Kapuas. Palangka Raya: Sekolah Tinggi Agama Islam Negeri Palangka Raya, 2014.

3. Aufa N. Tipologi Ruang Dan Wujud Arsitektur Masjid Tradisional Kalimantan Selatan. Journal of Islamic Architecture 1: 2, 2012.

4. Azra A. Islam Nusantara, Jaringan Global dan Lokal. Bandung: Mizan Media Utama, 2002.

5. Badri Yatim. Sejarah Peradaban Islam. Jakarta: PT.RajaGrafindo Persada, 2014.

6. Birin. Wawancara. 2019.
7. Darmawijaya. Kesultanan Islam Nusantara. Pustaka Al-Kautsar, 2010.

8. Eddy Sucipto. Wawancara. 2019.

9. Eka Dolok Martimbang. Profil Insan Muslim Kalimantan. Palangka Raya: CV Perak Nusantara, 2015.

10. Gusti Muhammad Maulana K. Wawancara. 2019.

11. Imam Qolyubi. Membongkar Belantara Gelap Sejarah di Tanah Pegustian dan Pangkalima Kalimantan. Daun Lontar, 2015.

12. Kartodirdjo S. Sejarah Nasional Indonesia III / Sartono Kartodirdjo, Marwati Djoened Poesponegoro, Nugroho Notosusanto. Departemen Pendidikan dan Kebudayaan, 1975.

13. Omar Usin. Wawancara. 2019.

14. Pranoto SW. Teori dan metodologi sejarah: Suhartono W. Pranoto. Ed. I. Graha Ilmu, 2010.

15. Qomarudin. Wawancara. 2019.

16. Sjamsuddin H. Metodologi sejarah / oleh Helius Sjamsuddin. Proyek Pendidikan Tenaga Akademik, 1996.

17. Tahir Q, Cangara H. Masjid Kampus Sebagai Media Komunikasi Aktivis Dakwah Dalam Pembentukan Karakter Mahasiswa. KAREBA : Jurnal Ilmu Komunikasi 3: 186-192, 2016.

18. Taufik Kurahman. Wawancara. 2019.

19. Trimbun Mandomai. Sejarah Singkat Keluraham Mandomai. 2013. 